\title{
Ethnoecology of paddy-fish integrative farming (minapadi) in Lampegan Village, West Java, Indonesia
}

\author{
IIK NURUL FATIMAH ${ }^{1}$, JOHAN ISKANDAR ${ }^{2}$, RUHYAT PARTASASMITA ${ }^{2, \bullet}$ \\ ${ }^{1}$ Biology Graduate Program, Faculty of Mathematics and Natural Sciences, Universitas Padjajaran. Jl. Raya Bandung-Sumedang Km 21, Jatinangor, \\ Sumedang 45363, West Java, Indonesia \\ ${ }^{2}$ Department of Biology, Faculty of Mathematics and Natural Sciences, Universitas Padjajaran. Jl. Raya Bandung-Sumedang Km 21, Jatinangor, \\ Sumedang 45363, West Java, Indonesia. Tel.: +62- 22-7797712.`email: ruhyat.partasasmita@unpad.ac.id, rp2010rikkyo@gmail.com
}

Manuscript received: 17 October 2020. Revision accepted: 30 August 2020.

\begin{abstract}
Fatimah IN, Iskandar J, Partasasmita R. 2020. Ethnoecology of paddy-fish integrative farming (minapadi) in Lampegan Village, West Java, Indonesia. Biodiversitas 21: 4419-4432. In the past, the traditional paddy-fish integrative farming (minapadi) was predominantly undertaken by rice farmers in West Java, particularly in the water abundant areas. Currently, however, the practice of the rice-fish system has been dramatically reduced due to the Green Revolution programs, including water pollution that may have affected fish farming in paddy fields. Although the rice-fish systems have rarely been practiced in West Java villages, some farmer groups of Lampegan Village, Ibun Sub-district, Bandung District are still practicing the rice-fish farming system. The purpose of this study is to collect and document the traditional ecological knowledge (TEK) of Lampegan Village about the rice-fish system farming managements, including data on various fish species that are widely cultivated in the community, cultural practices of the rice-fish farming management, and benefits of the rice-fish farming system. A combination of qualitative and quantitative methods was used, with an ethnoecological approach. Techniques of data collection, such as observation, semi-structured interviews, or deep interviews, and structured interviews were employed in this study. The results of the study show that the farmers of the rice-fish farming in Lampegan Village, Bandung District own rich and deep knowledge of fish species and practice of the minapadi system. The TEK of the rice-fish farming management system has been inherited from ancestors and is mixed with western scientific knowledge. The rice-fish farming systems have provided some ecological and socio-economic benefits for village people.
\end{abstract}

Keywords: Ethnoecology, fish species, rice-fish farming management, TEK, West Java

\section{INTRODUCTION}

In the past, rice farmers in West Java, especially in areas with a lot of water, practiced rice cultivation combined with maintaining fish which was known as the rice-fish integrative farming (sistem minapadi). Minapadi is an integrated farming system that is used by farmers to combine techniques of rice and fish cultivation which are carried out together in a single paddy field. This program aims to help farmers improve their welfare because, in addition to receiving revenue from the sale of rice, farmers also get additional revenue from the sale of fish that are cultivated together with rice (Rahmawati 2018; Kusnaka. 1994; Hadi 2014). The practice of rice-fish farming is a form of cultural adaptation of rural farmers in West Java to local ecosystems where water is widely available. The farmers manage the rice-fish farming based mostly on Local Knowledge (LK) or Traditional Ecological Knowledge (TEK), culturally (cf. Berkes 2008). The TEK of villagers on the rice-fish integrative farming is inherited from ancestors as well as gained from personal experiences. Therefore, rice-fish integrative farming is strongly influenced by local ecological conditions and the socio-economic cultural system of the local community.

The minapadi system traditionally practiced by rice farmers in West Java has many ecological, economic, and social benefits for the community (Sastrawijaya 1994; Nurhayati 2016; Wardiningsih et al. 2018). Ecologically, the minapadi system can create more loose and fertile rice fields (Halwart 1998; Halwart and Gupta 2004). In addition, the presence of several species of fish in the rice fields can control some types of rice pest insects (Luo et al. 2014). Economically the rice-fish farming system can increase paddy production from rice and fish yields so that it can increase farmers' income, while in terms of social and cultural aspects, the community gets better food quality (Nurhayati 2016).

However, today the practice of rice-fish integrative farming is diminishing in West Java. Intensification by optimization of existing land use by implementing integrated farming may help to overcome the problem of decreasing agricultural land, ensure supply of rice as a staple food, and increase fish production on par with increasing demand (Abuasir et al. 2004). With this objective, the Government of Indonesia, through the Ministry of Maritime Affairs and Fisheries, came up with the idea of using limited land resources in the form of Minapadi Program 2017 (Rahmawati 2018). The Ministry made minapadi its main program priority in 2018 due to the benefits gained from mina rice, which is of better quality and environmentally friendly (KKP 2018). Though potential minapadi land in Indonesia is around 4.9 million ha; so far only about 129,000 ha $(2.63 \%) t$ of the land is used for minapadi cultivation and another 4,000 ha was added 2017. In line with that, the West Java Regional Government, through the Head of the Food and 
Horticultural Service Office of West Java Province, has initiated a program to re-develop the rice-fish system in 16 districts/cities covering around 2,360 $\mathrm{Ha}$, while the minapadi cultivation business in Bandung covers an area of 4,480.59 Ha. (Dispakan 2016). Bandung District Government encourages the cultivation of minapadi fish, and the development of fish culture technology reaches 279.86 Ha., spread across seven districts. Besides, in ten other districts, 1,230 Ha of fish enlargement cultivation areas were also recorded (Dadang MN 2020, pers. Com.). Minapadi also has other benefits and advantages in ecological, economic, and social terms. However, the revitalization of minapadi system is not easy because of the changes in ecological factors and the socio-economic system due to the Green Revolution program introduced in the early 1970s.

Various studies on the rice-fish integrative farming have been carried out so far, such as the fish species cultivated, management systems, and economic benefits (Admihardja 1994; Cahyaningrum 2014; Hadi 2014; Nurhayati 2016; Lantarsih 2016; Akbar 2017; Lestari 2017). However, a study of the rice-fish integrative farming with an ethnoecological approach, involving the assessment of the practice of rice-fish practices (praxis) based on associated Traditional Ecological Knowledge (corpus), such as the beliefs of villagers (Toledo 2002; Berkes 2008), has been rarely reported.
Lampegan Village, Ibun Sub-district is one of the villages in West Java Province which is practicing rice minapadi system since the 1970 s, and rice-fish integrative farming is continuing here. The major defense in favor of the rice-fish farming system in the village is thought to be related to the social belief about preserving the culture of rice-fish integrative farming, in addition to its economic and ecological benefits. The objectives of this study are to analyze the local knowledge or TEK of the farmers on fish species, management of the rice-fish integrative farming, and the various benefits of the rice-fish integrative farming.

\section{MATERIALS AND METHODS}

\section{Study area}

The research was conducted in Lampegan Village, Ibun Sub-district, Bandung District, West Java Province, Indonesia (Figure 1). Geographically, Ibun Sub-district is located between $7^{\circ} 15^{\prime}-7^{\circ} 80^{\prime} \mathrm{S}$ and $107^{\circ} 33^{\prime}-107^{\circ} 38^{\prime} \mathrm{E}$, with an altitude of $700 \mathrm{~m}$. The area consists of slopes or ridges. This village consists of 3 villages, with 11 Rukun Warga $(R W)$, which is divided further into 27 Rukun Tetangga or $R T$ (Neighborhood Unit). The north area in Lampegan Village is bordered by Tanguluan Subdistrict, south is bordered with Cibeet Village, east is bordered by Talun Village and Sudi Village, and the west area is bordered by Karyalaksa Village.
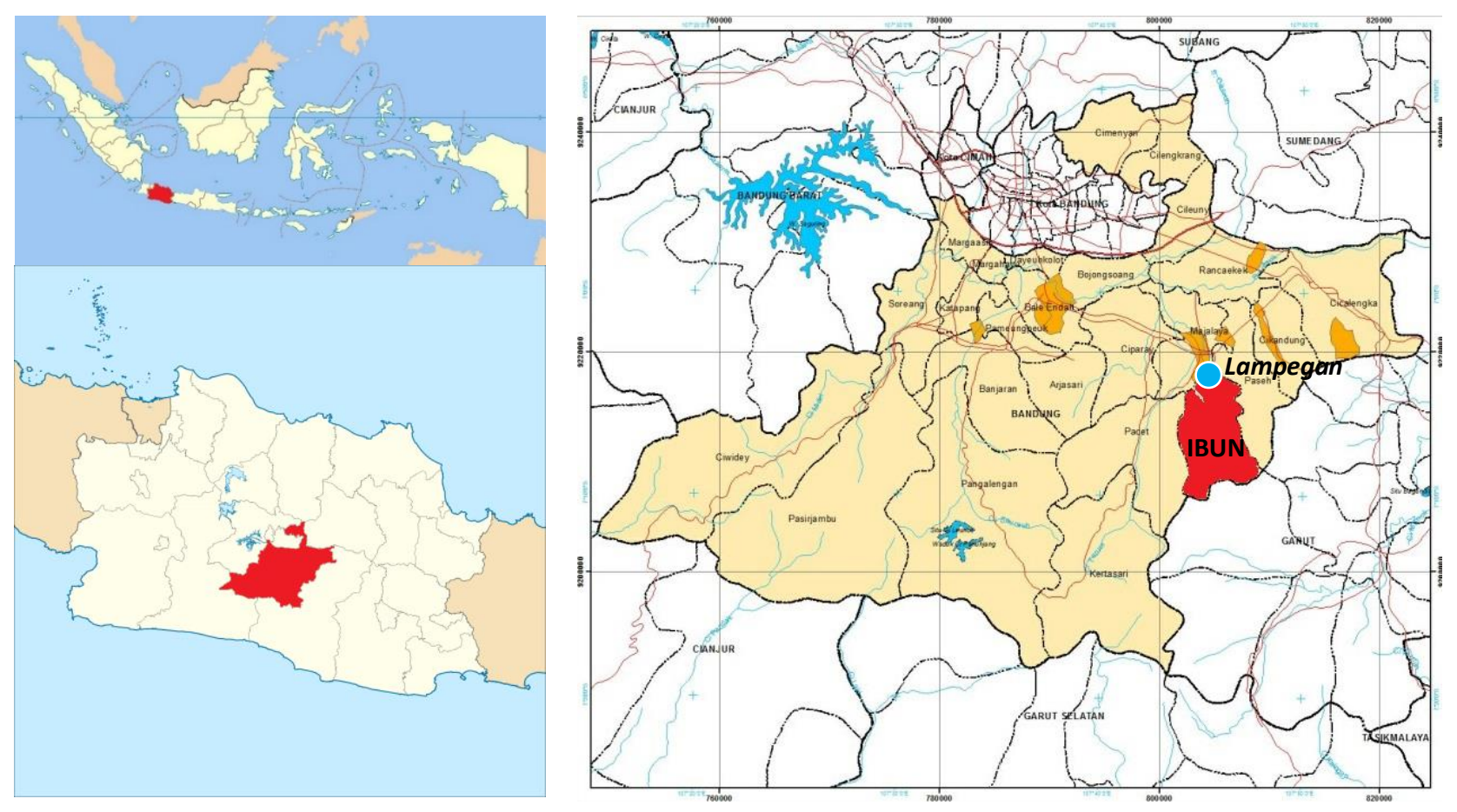

Figure 1. Map of research locations in Lampegan Village, Ibun Sub-district, District Bandung, West Java, Indonesia 


\section{Methodology}

The study was conducted from October 2019 to March 2020, by using mixed-method, i.e., by the combination of the qualitative and quantitative methods with an ethnoecological approach (Toledo 2002; Albuerque et al. 2014; Iskandar 2018). The prefix 'ethno' in ethnoecology is used with two meanings. In the meaning originally intended in ecology, it refers to ethnicity - a study of the ecology of a particular ethnic group - something unique to the history of that group. Here the term 'ethno' means more of a concept involving the cultural insider's cognition than an outsider's observations (Fowler 2000). In other words, the ethnoecological approach is to emphasize the study of traditional ecological knowledge (TEK) in a culture closely related to the local people to the interaction between the local people and the environment in managing fishes in the rice-fish studied by researchers or outsiders (cf. Albuquerque et al. 2009; Toledo 2002; Berkes et al. 2003). The assessment was conducted by integrating 'emic' and 'ethical' analysis. Emic's analysis examines the traditional ecological knowledge of the population in a culture that is closely related to the management of the rice-fish, carried out by local people in Lampegan Village. Then, this aspect of emic was analyzed in an ethical view, by Western scientific knowledge to understand the traditional ecological knowledge of local people in a cultural way (Lovelace 1984).

Techniques employed for data collection are observation, semi-structured interviews, deep interviews, and structural interviews. The observation was to collect data about the condition of the rice fields which were used for rice-fish management. Semi-structured interviews or deep interviews were conducted to gather information on various processes, such as the process of managing the rice-fish farming before and after the Green Revolution program. Semi-structured interviews were conducted with informants who were farmers active in the management of rice-fish farming, such as hamlet heads, village heads, and fish dealers in the village selected purposively using the snowball technique. This snowball technique was used to select competent informants based on the instructions of the community members. For example, to find competent informants as local experts in the management of the ricefish, researchers first contact the base informants, such as the village head and hamlet head $(R K)$. From these base informants, details of the local experts in the community at the study site were collected. More informants were added to the list by contacting these informants and this is continued as a chain so that the maximum of the knowledgeable and competent informants are involved in during research (Alburquerque et al. 2014).

In semi-structured interviews, the informant's extensive responses to a series of general questions, some of which had been prepared in advance and some of which appeared naturally during the conversation were recorded (cf. Martin, 1995). The informants were selected from 50 farmers, who were gathered in 5 groups, from the rice-fish association in Lampegan Village.

\section{Data analysis}

Quality data collected by observations and different types of interviews were analyzed by cross-checking, summarizing, synthesizing, and making narrations (Newing 2011). Quantitative data collected through structured interviews with respondents were analyzed statistically. Finally, the results of both qualitative and quantitative analyses were integrated into a complementary unit and narrated in the form of a descriptive analysis.

\section{RESULTS AND DISCUSSION}

The rice-fish integrative farming has long been conducted by local people in Lampegan Village. In the past, farmers cultivated varieties of local rice (paré buhun), such as paré randa kaya, paré fajar, paré warnéng, paré ranggaling and paré ceré. The farming practice was strongly based on TEK and trust. Farmers start planting rice using a variety of traditional calculations (paririmbon), and some customary measures related to farmers' belief that rice has a rice goddess called Nyi Pohaci or Dewi Sri in West Java.

Rice which is the main crop in the rainy season is planted once a year, but in the dry season, rice planting is done in combination with spreading fish on land that has been planted with rice, namely the intercropping minapadi system. The rice-fish integrative farming is The minapadi system is carried out as an intervener after the rice harvest and / or intercropping with rice, planted in the fields when rice planting is still small. This agricultural system business activity is used as additional income from paddy field farming which is obtained by farmers in addition to income from the rice harvest.

At present, rice-fish integrative farming is still being conducted by some people in Lampegan Village. About 50 people registered in 5 groups are still actively managing rice-fish management.

\section{People's knowledge about fish}

As Sundanese people in general, the people of Lampegan Village recognize fish with its vernacular name "lauk". At present, various species of fish (rupirupi lauk) are usually cultivated in the rice fields, locally known as 'melak lauk di sérang'. The most dominant is common carp fish (Cyprinus carpio) and tilapia (Ostheochilus haselti). Besides, some ornamental fishes (lauk hias), such as koi (Cyprinus carpio haematopterus), chef (Carassius auratus), oscar (Carassius auratus), manfish (Pterophyllum scalare), comet (C. auratus), and platis (Xiphophorus maculatus) as well as ordinary residents are raised.

Lampegan Village residents can recognize the species of fish (rupi-rupi lauk), and they can also distinguish variations (races) of a species of fish. For example, according to the informants, common carp (Cyprinus carpio) can be divided into 3 races, i.e., common carp fish 'sinyonya', common carp of 'punten', and common carp fish of 'majalaya', based on body shape, eye shape, and color of fish scales (Table 1 and Figure 2). 
Another species of fish, tilapia (Osteochilus hasselti) can also be divided by the into 5 races, namely gip, nirwana, filipin, gesit, biasa, distinguished primarily based on the body color of the fish. as summarized in Table 2 and shown in Figure 2.

Besides, the folk classification distinguished fishes based on different aspects like fish maintenance goals (lauk hias and lauk non-hias), water quality (very good water quality/saé caina and less good/kirang saé caina), consumption value (consumed and not consumed/used as ornamental fish), body size (big fish/ageung and small fish/lauk alit), and the market price (expensive/cheap fish and lauk mirah/lauk awis (Tablet 3).

Besides, the species of fish cultivated in the rice-fish farming management is also be classified by the people of
Lampegan Village based on the size of the fish seed. The size of seeds that are bred in rice-fish includes kebul, putihan/gelas, belo/léter, and ngadua ramo/kilo (Table 4). Fish seeds commonly stocked on rice-fish land in the Lampegan Village community are the size of putihan/gelas and belo/leter. This site is considered the most ideal and suitable to be maintained in rice fields.

The folk classification of fishes used in the rice-fish integrative farming in Lampegan Village is almost the same as the folk classification of Karangwangi Village, Cianjur, and Kasepuhan Gunung Halimun, Sukabumi, West Java, where freshwater fishes are classified based on body size, the color of scales, habitat, size of a seed, and taste/culinary of fish (Admihardja 1994; Erawan et al. 2017; Partasasmita et al. 2015).

Table 1. Variations (races) of common carp (Cyprinus carpio) according to villagers of Lampegan Village, Ibun Sub-district, Bandung District, West Java Province, Indonesia

\begin{tabular}{|c|c|c|c|}
\hline \multirow[t]{2}{*}{ Local name } & \multicolumn{3}{|c|}{ The distinguishing characteristics of the eyes, scales, and body of the fish } \\
\hline & Eye & Scale & Body shape \\
\hline $\begin{array}{l}\text { Emas } \\
\text { sinyonya }\end{array}$ & $\begin{array}{l}\text { mata lauk nu ngora teu nonjol, lamun } \\
\text { laukna enggeus déwasa matana sipit } \\
\text { (eyes of younger fishes don't stand } \\
\text { out, and the adult fishes have slanted } \\
\text { eyes) }\end{array}$ & $\begin{array}{l}\text { sisit laukna warna konéng } \\
\text { (light yellow scales) }\end{array}$ & $\begin{array}{l}\text { ukuran laukna panjang (relatively long body } \\
\text { size) }\end{array}$ \\
\hline Punten & $\begin{array}{l}\text { matana rada nonjol (eyes stand out a } \\
\text { bit) }\end{array}$ & $\begin{array}{l}\text { sisik laukna héjo rada } \\
\text { hideung (black-green scales) }\end{array}$ & $\begin{array}{l}\text { tonggonggna rada luhur katingalina } \\
\text { ukurana leuwih pendék dibanding ras } \\
\text { sejenna (the back looks taller and shorter in } \\
\text { size compared to other races) }\end{array}$ \\
\hline Majalaya & $\begin{array}{l}\text { Matana gedé, } \\
\text { (big eyes) }\end{array}$ & $\begin{array}{l}\text { Sisitna héjo rada abu, } \\
\text { gigirna leuwih hideung } \\
\text { (gray-green scales with } \\
\text { darker edges) }\end{array}$ & $\begin{array}{l}\text { rada péndék atawa betekok. wujud tuwuhna } \\
\text { lancip ka tonggong, moncongna ipis } \\
\text { (body size is relatively short or called } \\
\text { batekok, body shape is tapering towards the } \\
\text { back and snout is flat) }\end{array}$ \\
\hline
\end{tabular}

Table 2. Variation/races of Tilapia (Osteochilus hasselti) according to Lampegan Villagers, Ibun Sub-district, Bandung District, West Java Province, Indonesia

\begin{tabular}{ll}
\hline Local name & Characteristics of body- color \\
\hline Gip & Warna tuwuhna hideung mibanda garis-garis di tuwuhna (Black body color, has body lines) \\
Nirwana & Warna tuwuhna abu-abu rada héjo jeung warna beuteungna bodas rada abu-abu (The body color is greenish-gray \\
& and the color of the stomach is white to grayish gray) \\
Filipin & Warna tuwuhna campuran antara bodas jeung rada konéng (Mixed body color between reddish, white, and slightly \\
& yellow) \\
Gesit & Warna tuwuhna hideung, mibanda cécépét kandel (Body-color is black, has thick fins) \\
Biasa & Warna tuwuhna hideung rada abu-abu, dina beuteungna leuwih boléas (Black body color rather gray, brighter \\
& abdomen)
\end{tabular}

Table 3. Folk Classification of fishes in Lampegan Village, Ibun Sub-district, Bandung District, West Java Province, Indonesia

\begin{tabular}{ll}
\hline Criteria & Categories and examples \\
\hline Based on water quality & Lauk dina cai nu saé (need good water), common carp and ornamental fish \\
& Lauk nu kiat dina cai nu kirang (adapted in water whose quality is not good) tilapia \\
Based on consumption utilization & Lauk kanggo diemam (consumed), common carp and tilapia fish \\
& Lauk hias (ornamental fish), koi, chef, comet, manfish, platis, oscar. \\
Based on culinary taste & Lauk nu raos (tastes good) common carp fish \\
& Kirang raos (taste not good) tilapia, \\
Based on the selling price of fish & Lauk awis (expensive) goldfish, ornamental fish; \\
& Lauk mirah (cheap), tilapia \\
Based on fish body size & Lauk ageung (big body) common carp fish \\
& Lauk leutik (small body) tilapia and ornamental fish \\
\hline
\end{tabular}


Table 4. Categories of fish in the rice-fish integrative farming of Lampegan Village, Ibun Sub-district, Bandung District, West Java Province, Indonesia based on seed size

\begin{tabular}{lll}
\hline Seed size & Information & Weight \\
\hline Kebul & Freshly hatched fish seeds & - \\
Putihan/gelas & Fish seeds are still in the form of larvae and looked white. & $1500-2000$ individual fishes/glass \\
& Usually cured using a glass. & \\
Belo/léter & Fish seeds were measured using léteran béas (rice filter device) & 200 individual fishes/léter \\
Sangkal/ngadua ramo/kilo & A fish is the size of two adult fingers & 50 individual fishes/kilogram \\
\hline
\end{tabular}

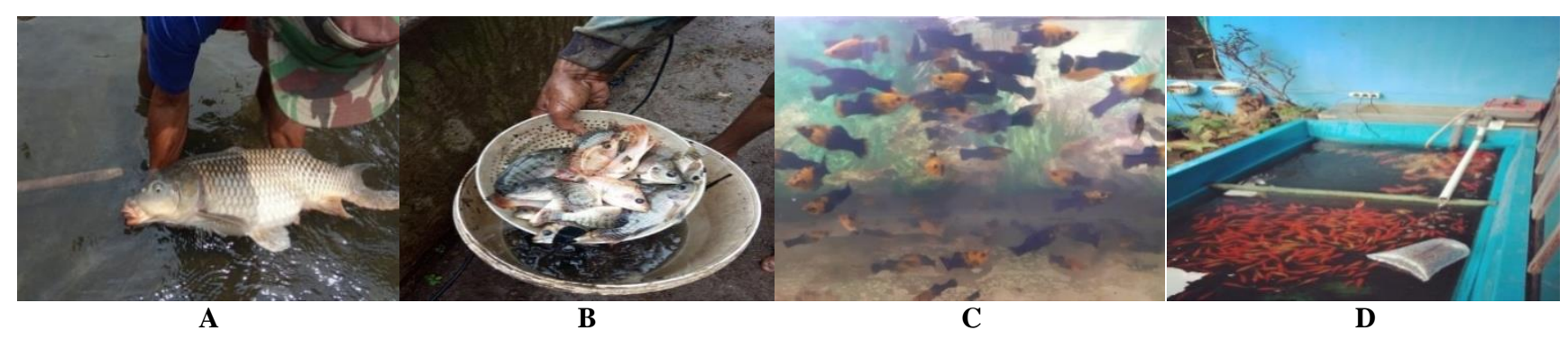

Figure 2. A. Majalaya - common carp fish B. Gip and filipin tilapia C and D. Lauk hias (ornamental fish)

Based on the results of a structured interview with respondents of Lampegan Village who practice the ricefish integrative farming, popularly cultured fishes are common carp and tilapia, which is almost $52 \%$ (Table 5). A farmer breeds these two species of fish in his different rice fields at the same time. This depends on the suitability of the fish species for the quality of water in the rice field. By having two species of fish in their rice field, farmers will get greater profits, due to the diversity of the fishes available. In addition, by growing common carp and tilapia, farmers maintain the diversity of fish species.

There are several reasons for the selection of fish seeds by the people of Lampegan Village, such as the availability of government assistance, easy management, and focus on fish sales (Table 6). The most dominant reason in the selection of fish seeds by the community is the ease of management, which amounts to around $74 \%$. Lauk emas are the most chosen to be raised in rice-fish farming management because they are growing faster and easy for farmers to maintain. Also, lauk emas is perceived by residents as the most superior type cultivated in Majalaya because according to the ecological history of the local fish race, Majalaya has long been raised for generations in the Lampegan region, which was previously part of the Majalaya sub-district.

According to local perception including the classification of fish that can adapt to good water quality, common carp is usually consumed either in large or small sizes usually called ukuran lauk impun. It tastes better and more delicious than those kept in ponds. Besides, tilapia is also maintained because of its ease in management and high survival.

According to minapadi farmers, tilapia can adapt better to the low quality of water and it is also resistant to predators. Tilapia usually hide behind rice plants in rice fields, due to the size of the body, being smaller than goldfish. Also, tilapia is more widely developed because of its ease of cultivation although the selling price is relatively cheaper than other species of fish.

Meanwhile, ornamental fishes are developed in the ricefish integrative farming in Lampegan Village only for commercial purposes and hobbies from the community but not for consumption. One group in Lampegan Village is a special group for marketing ornamental fishes in Ibun Subdistrict, Bandung District.

Table 5. Species of Fish cultivated in the Rice-Fish Integrative Farming by Lampegan Villagers, Ibun Sub-district, Bandung District, West Java Province, Indonesia

\begin{tabular}{lcc}
\hline Fish species & $\begin{array}{c}\text { Respondents } \\
\text { (individual) }\end{array}$ & $\begin{array}{c}\text { Percent of the } \\
\text { total (\%) }\end{array}$ \\
\hline Common carp & 6 & 12 \\
Tilapia & 6 & 12 \\
$\begin{array}{l}\text { Ornamental fish } \\
\text { Common carp fish and tilapia }\end{array}$ & 3 & 6 \\
$\begin{array}{l}\text { Common carp fish, tilapia and } \\
\text { ornamental }\end{array}$ & 9 & 52 \\
Total & 50 & 18 \\
\hline
\end{tabular}

Table 6. Reasons for selecting Fishes for cultivation in the RiceFish Integrative Farming in Lampegan Village, Ibun Sub-district, Bandung District, West Java Province, Indonesia

\begin{tabular}{lcc}
\hline Reasons & $\begin{array}{c}\text { Respondents } \\
\text { (individual) }\end{array}$ & $\begin{array}{c}\text { Percent of } \\
\text { total (\%) }\end{array}$ \\
\hline Government assistance & 10 & 20 \\
Easy to manage & 37 & 74 \\
Focus on fish sales & 3 & 6 \\
Total & 50 & 100 \\
\hline
\end{tabular}


The selection of species of fish stocked can vary by region based on local ecosystem conditions, such as the quantity and quality of water, people's preference, and fish potential in the area. In other areas in West Java, such as in the areas of Ciparay, Cianjur, and Cisolok, Sukabumi, farmers of the rice-fish management usually raise common carp fish (Cyprinus carpio), tilapia fish (Oreochromis mossambicus), tilapia (Oreochromis niloticus), and nilem fish (Osteochilus vittatus) (Admihardja 1994; Nurhayati 2016). Whereas the farmers of the rice-fish integrative farming in Subang raise tawes (Barbonymus gonionotus), common carp (Cyprinus carpio), nilem fish (Osteochilus vittatus), and kancra (Tor) (Sasa 2006; Sudiarta et al. 2016). Rice-fish farmers in the Nganjuk region, Central Java, generally raise catfish (Clarias batrachus) (Lestari 2017).

\section{Management of the rice-fish integrative farming}

The people of Lampegan Village usually call the period of the Green Revolution as "era Pak Soeharto" because Mr. Soeharto was the president when the program was implemented. During this period, the rice-fish integrative farming or melak lauk di sérang began to receive more attention from the community. The rice-fish farming was not only to fulfill the nutritional needs of the family by way of fish consumption, but fishes were also sold or marketed to cities in need of seeds and large size fishes (kiloan).

The rice-fish management in Lampegan Village, starting receiving fisheries counseling in the 1970s from the Fisheries Department, which started to visit villages to conduct training in the form of maintenance and assistance in the distribution of broodstock, seeds, and fish feed.

Besides, the rice-fish system also began to bloom in the community due to an increase in ponds. However, the land which was originally large now has narrowed due to housing and other construction activities. Management of the rice cultivation system is carried out twice a year, but now organic fertilizers are replaced with inorganic fertilizers, such as urea and TSP. For fish, feed is also added with the use of dedek (leftover rice in rice mills).

From the year 2000 onwards, people of Lampegan Village began to form farmer groups to facilitate the distribution of aid and the development of farming. There are now 7 such groups, two of the groups focus on fisheries marketing. Rice-fish farming management or melak lauk di sérang began to spread to farmers who had never done this activity in the Green Revolution era. Farmers who previously only focused on maintaining rice in the fields participated in rice-fish farming activities. In addition to the inherited knowledge, they also gained knowledge about rice-fish farming from the group leader who routinely conducted the extension of rice-fish farming management (melak lauk di sérang). In 2016, The Bandung District Fisheries Service, together with the Agriculture and Food Service, provided 7-8 quintals of fish seeds to Lampegan Village, as well as rice seeds, and other necessities.

During the Green Revolution period, Darsono dam was built which was used as water sources for the irrigation system of Lampegan Village. This dam is in Cibéét Village which is now used interchangeably for agricultural activities and fisheries activities. The problem that occurs at this time is the reduced amount of water and the water from Citarum River which is tainted, and erratic rainfall makes the activities of melak lauk di serang somewhat reduced. However, some residents at the top area of Lampegan Village rarely experience water shortages and are still able to practice the rice-fish integrative farming even during non- rainy season.

\section{Time management of rice-fish integrative farming}

The farmers in Lampegan Village no longer rely on the traditional calendar determined by the wali puhun. Wali puhun is an elder (sesepuh) in the village who has deep knowledge of farming (Suganda 1964). This is because the presence of wali puhun in the village has been greatly reduced, and traditional ecological knowledge is no longer conveyed to the younger generation. Besides, the influence of the Darsono dam with its irrigation system has altered the rice planting season. Rice-fish farmers in Lampegan Village usually adjust the planting time with farmers in the same block in their area.

Farmer communities in Lampegan Village are no longer planting rice simultaneously but adjusted to the rice fields in each rukun warga $(R W)$. If the rice field blocks are located in strategic irrigation locations or have never experienced water shortage problems in the dry season, cultivation activities are done routinely, following the specified times each year. Planting rice is usually carried out three times a year. Farmers who are in rice fields experiencing drought in the dry season usually start planting rice in the rainy season or usually coinciding with the end of the year, such as November or December. If there is a long dry season, the farmers in the rice block only plant rice, not fish in the rice field due to poor water availability.

Two different models are followed for fish farming in the rice fields, which are called intermittent and intercropping models (Figure 3). In the intermittent model, fishes are usually cultured in the rice fields after the rice harvest, before there planting of rice. In the intercropping model, fishes are cultured together with rice planting. According to the Ibun Village community, the intermittent model is more profitable compared to other systems because it is easier to manage. 


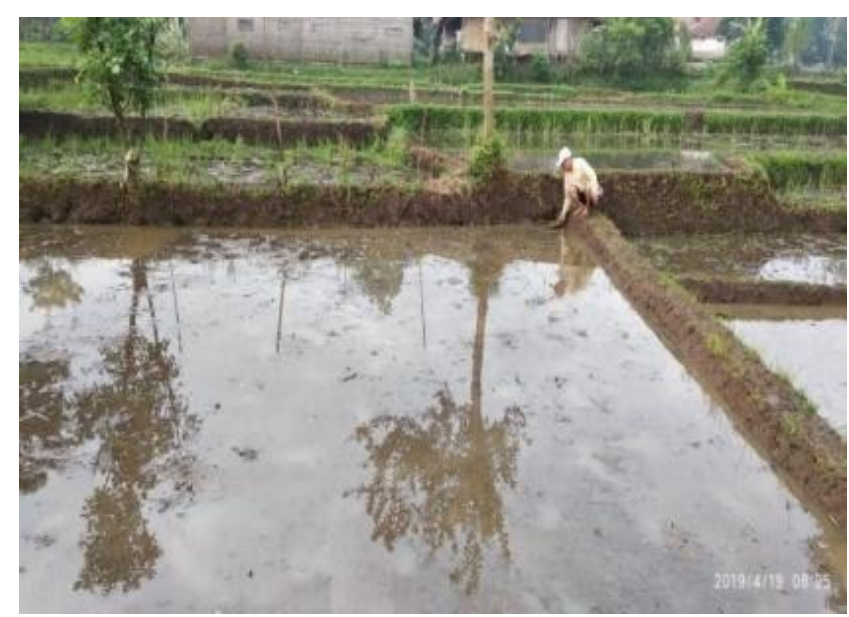

A

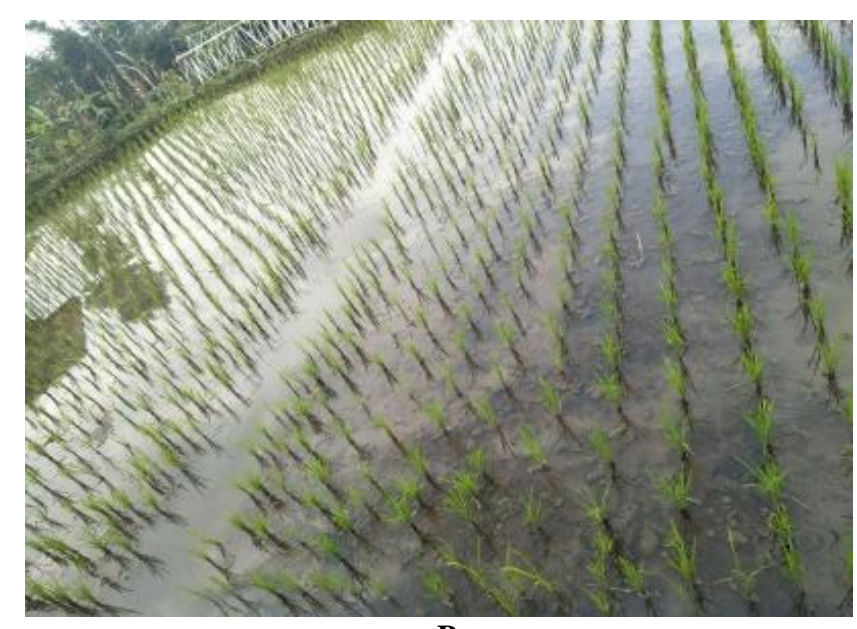

B

Figure 3. Rice-fish farming models. A. The intermittent model, B. The intercropping model

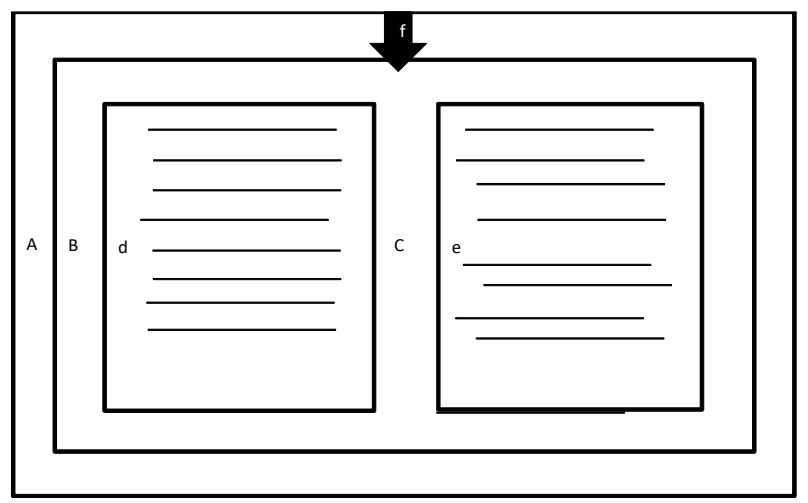

Figure 4. Forms of trenches in the rice-fish integrative farming; (A) dyke of a rice field (galengan), and (B), (C), (D), and (E) the trenches, and $(\mathrm{F})$ waterways of the bamboo stem to drain water from other rice fields

\section{The forms of the trenches of the rice-fish integrative farming}

The local people of Lampegan Village are highly concerned about the condition of their rice fields. They use dykes (galengan) to collect water in the rice fields and to drain water from one rice field to another a channel made of bamboo is used. In each of the rice fields on the edge of the embankment around the rice field and the middle of the rice field, special trenches are made for fishing grounds (Figure 4). Rice fields stocked with fish are usually marked by bamboo stakes with white plastic slipped in them.

The length and depth of the trenches in each rice field are usually adjusted to the width of the rice fields. Farmers measure the depth and length of trenches usually by using hoes (pacul). The depth of the trench is in line with the depth of the rice-fish integrative farming, which is usually the size of a hoe (pacul), about $30 \mathrm{~cm}$. The depth of the trench is also in line with practice elsewhere $(20-40 \mathrm{~cm})$ and the width in the middle of the rice field is $30-150 \mathrm{~cm}$ (Sastrawijaya 1994; Sasa 2006; Sudiarta et al. 2016).

According to informants, making trenches in rice fields is intended to facilitate the maintenance of fish, function as fish shelters when the water in the rice fields decreases and feeding sites for fish provides protection from pests, and they also make fish harvest easier.

\section{Rice-fish farming land preparation}

The first step in land preparation, namely ngababad jarami is clearing rice fields by cutting rice straw after the rice is harvested. In rice fields with fish culture, straw and plant residues are usually left in the rice fields. Then, in the dry season, the straw and grass are burned. However, in the rainy season, the rice straw is allowed to rot. It is believed by farmers that the remains of rotten straw will increase the fertility of rice fields. Also, rice straws are usually traded or given to other farmers to be used as fodder for cattle.

After harvesting rice, the farmers select rice fields that are specifically used for raising rice seedlings (pabinihan pare) for planting during the next season. Usually, farmers who have around 100 tumbak of rice fields ( 1 tumbak $=14$ $\mathrm{m}^{2}$ ), making rice seedlings around 10 tumbaks or about 15 $\mathrm{kg}$ of rice seeds. Seedlings are usually allowed to grow for 18-25 days. Simultaneously, the farmers prepare the land in other rice fields, in 2 stages. The first is called nyingkal, and the second is called nganglér (Figure 5).

Nyingkal is a process of rough plowing of rice fields. After plowing (nyingkal), the second step is (nganglér) carried out to smoothen the soil into $f$ mud. For this plowing, farmers generally employ farm laborers. Buffalos or tractors that are privately owned or rented from others are also used for plowing. Plowing with the help of a buffalo or tractor goes to level the ground and cleans grass and other plants in the fields (Handojo 1989).

After nganglér is finished, the farmer makes trenches (kamalir) to be used as a place for raising fish in rice fields. Kamalir is made with a hoe of $20-40 \mathrm{~cm}$ depth. Then, they proceed with the leveling of the rice fields (susurangan) with wooden boards. Leveling the rice fields is to facilitate planting rice. The next stage is to make lines with ticks (dicaplak) of boards by pulling using bamboo or wood sticks. Nyaplak is intended to keep the rice crop straight. At each point of the normal caplak line, 2-4 rice plants are planted. Similar to Lampegan Village, preparation for processing rice fields for fish cultivation in the rice fields under the rice-fish integrative farming is usually done perfectly, that is, plowing three times (Sasa 2006). 


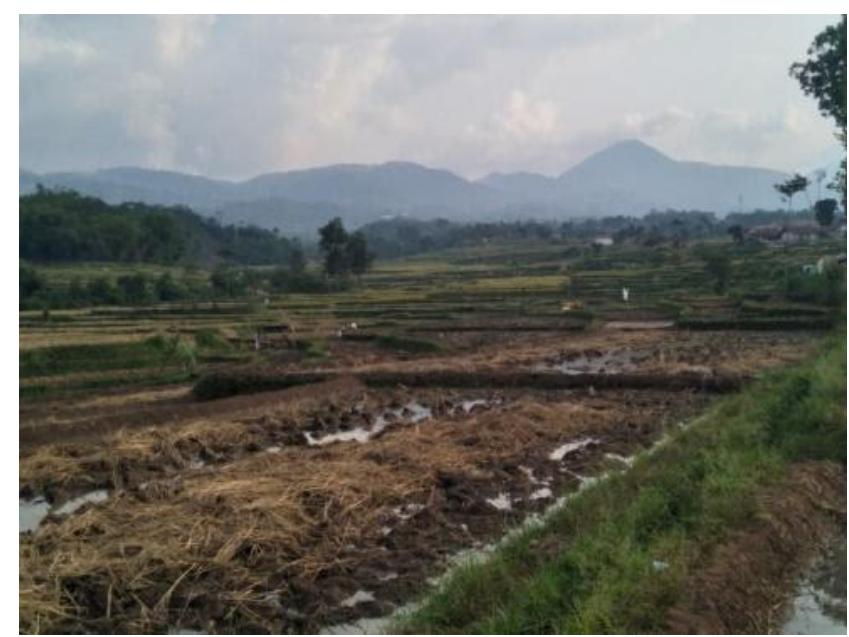

A

Figure 5. Rice field (A and B) is being hoed (nyingkal)

\section{Fish seed preparation (pamijahan)}

Spawning (pamijahan) of fish for the rice-fish farming system in Lampegan Village is usually done in the residents' private ponds. Some residents make spawning ponds in their rice fields (Figure 6). This is to facilitate the removal of seedlings from fish ponds to be released in rice fields (pendederan). Rice fish farmers who do not have a pond, usually buy seeds from cities or outside the Lampegan Village or get help from the local government.

In spawning, usually, the brood stock is put together in the same pond. Spawning methods vary according to the species of fish. For example, for common carp (Cyprinus carpio), usually, the male fish is combined with the female fish in one pool with a ratio of 1: 1 . In the pond, hapa/waring are usually prepared for a place of spawning, and kakaban is made from the dark fibrous bark of sugar palm (Arenga pinata) for females to lay their eggs (Figure 6). Spawning usually occurs at night. After the eggs hatch and stick to kakaban, the broodstock is taken and separated from the spawning pond. Fish eggs will hatch in kakaban in three days. In this process in kakaban, chemical agents are used to avoiding diseases or fungal infections. After the fish eggs hatch, larvae are transferred to other ponds without being fed until the age of three days. After the third day, fry is given only boiled egg yolk. After the age of 5 days, the fry is given a fine pellet and after 10 days the fish are given thick pellets.

In contrast to goldfish, tilapia (Osteochilus hasseltii) is not given kakaban or hapa/waring in the spawning pond. The broodstock of tilapia is usually allowed to live in spawning ponds, with a composition of 1 male tilapia for 3 female parent fish. After the eggs hatch, the broodstock of tilapia is taken and transferred to another pond. The reason for moving the fish is because the older will prey on their offsprings. In another method, the larvae of tilapia are caught with a siriban tool (a form of a fine net), by scooping out. Siriban is used because the holes in the net

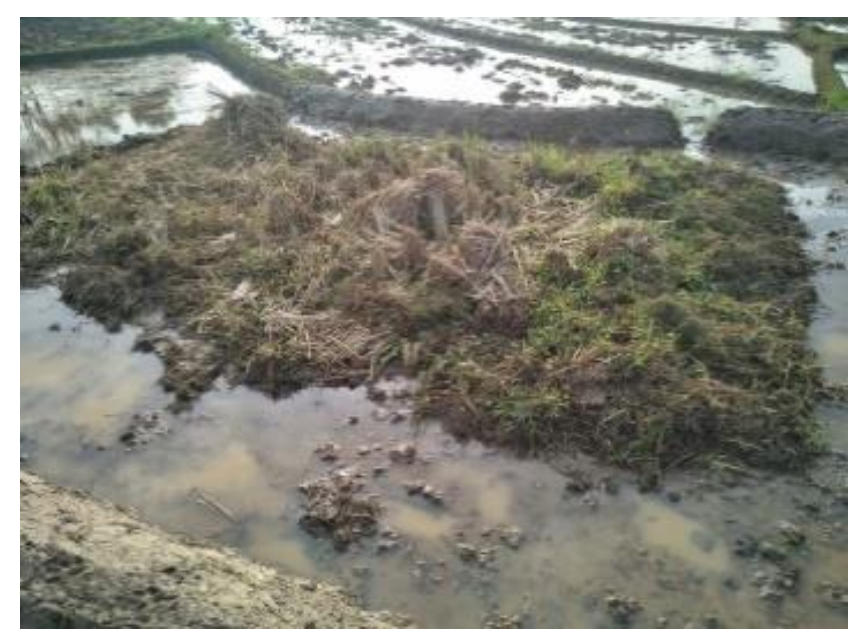

B

are tight, with no holes so the young fish don't escape and the number can be reduced when removed from the pond.

Quality of seed is one of the factors that can influence the success of the rice-fish business system. Good fish seeds can be produced from the spawning activity. However, not all farmers can spawn fish. Therefore, the easiest way to obtain fish seeds is by buying from fish seed breeders. In addition to buying fish seeds, farmers also often buy fish mothers to facilitate the spawning process later in the pond. In the process of spawning, broodstock mate in a pond naturally without any chemical addition.

\section{Sowing of seeds (pendederan) of fish in the rice-fish integrative farming}

According to informants, the seeds of tilapia that are spread into rice fields in the intercropping model of the rice-fish management are usually of belo/léter size. Meanwhile, goldfish seeds were sown in rice fields in the mineral system in the usual auctioning model use fish of belo/leter size to the size of sangkal/ngadua ramo. The seed density of fish stocked vary, starting from 1 léter to 7 kilograms of fish per tumbak $\left(14 \mathrm{~m}^{2}\right)$.

Fish spreading in rice fields in the rice-fish system can vary. In the f intercropping model, stocking of fish in the rice is carried out for a maximum of 30 days, when the rice is 30-40 days old. The community does rice-fish integrative farming 3 times a year, according to the rice-growing period. Meanwhile, in the intermittent model, fish are stocked in the rice fields for about 15-25 days until the rice seeds are ready to be planted in the fields. The seeds of fish that are stocked in the rice fields are around 20 days old. The process of spreading fish into the fields is done manually in the rice fields that have the water of only a foot height. Then the seeds of fish are sown in rice fields. The fish seeds that are stored in beg (plastic) or buckets are dumped into rice fields (Figure 7). 


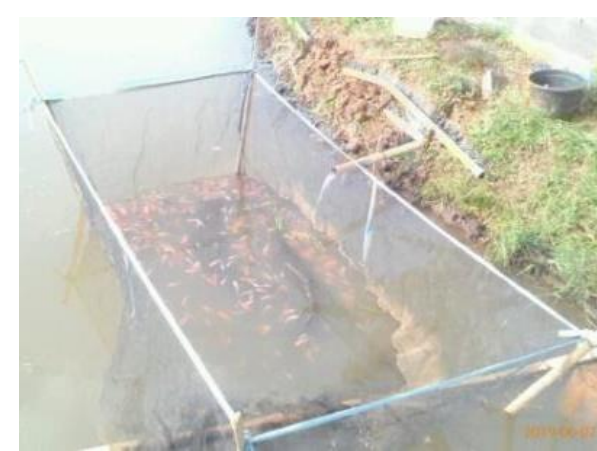

A

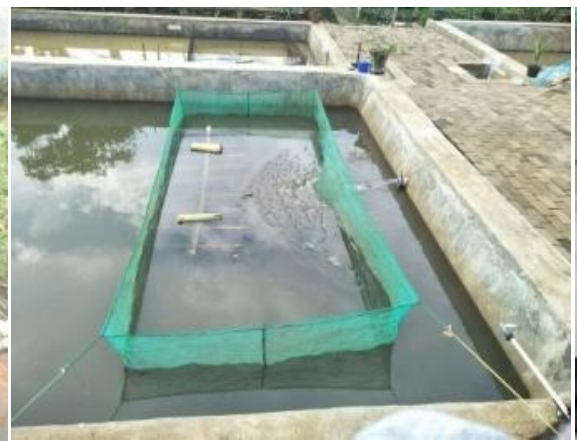

B

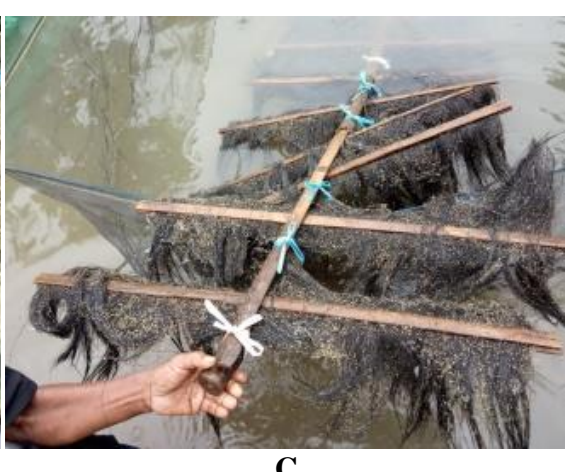

C

Figure 6. A. Fish spawning grounds in rice fields, B. Fish spawning grounds in ponds, C. Kakaban where they lay their eggs in ponds

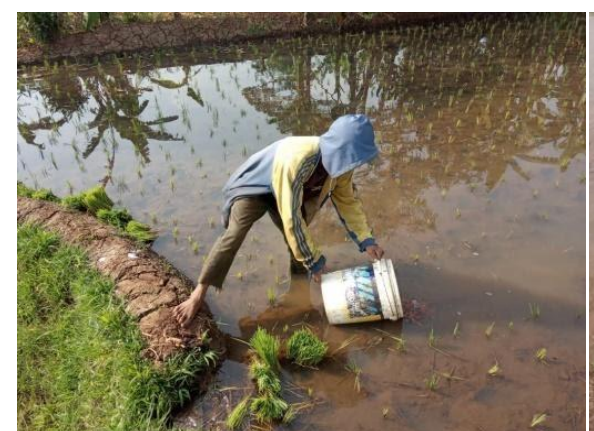

A

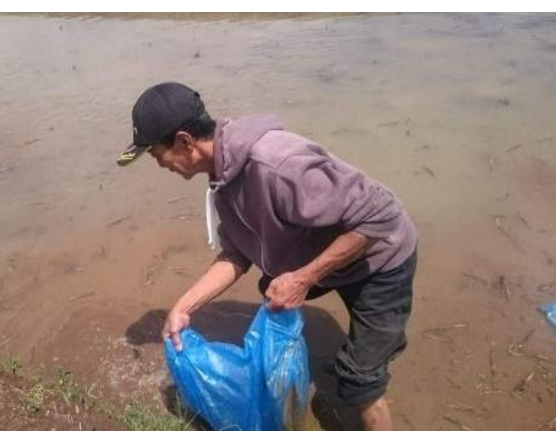

B

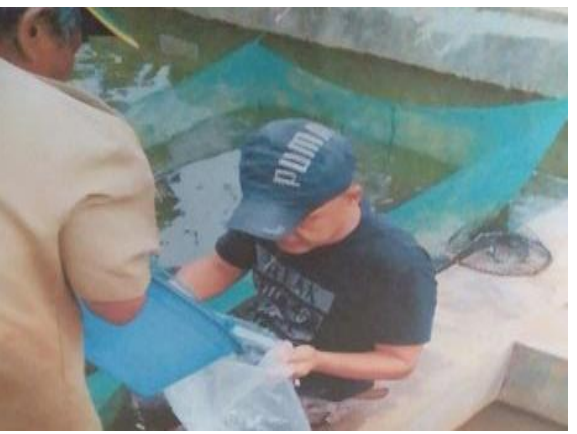

C

Figure 7. The process of stocking fish in rice fields (A, B) and collecting fish seeds (C) by farmers of the rice-fish integrative farming in Lampegan village

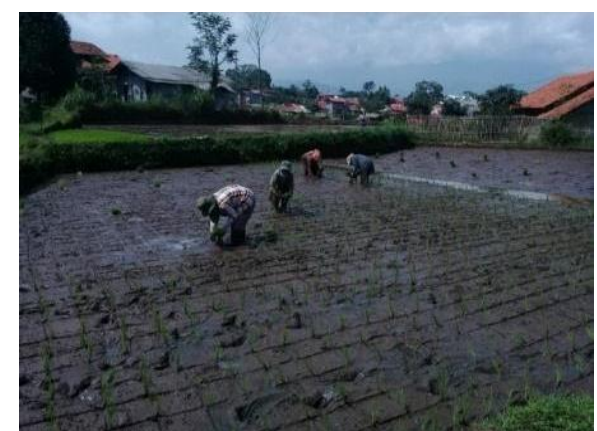

A

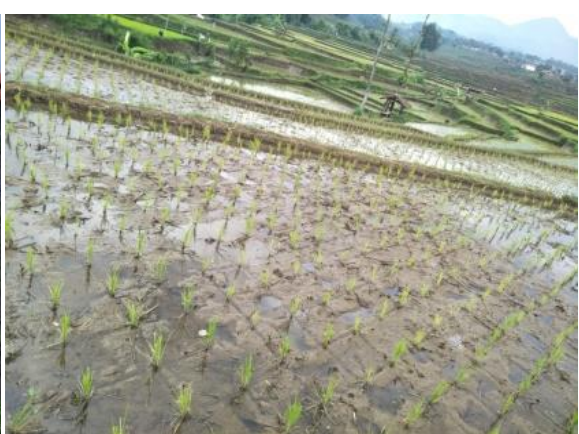

B

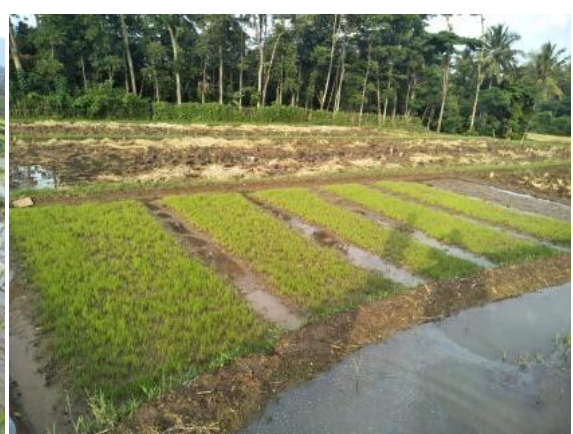

C

Figure 8. A. Transplanting in rice fields (tandur), B. A transplanted rice fields that have been previously marked, C. Seedbed for raising seedlings for transplantation

The process fish seed spreading of farmers in the village of Lampegan is almost similar to the habits of farmers practicing rice-fish integrative farming in other places. For example, the farmers of the rice-fish system in Bengkulu spread crispy baby fish of the size of kebul, after 5 days of rice planting, with a density of 30 thousand heads per hectare, with a maintenance period of 30-40 days (Hadi 2014). Meanwhile, for consumption purposes, $5-8 \mathrm{~cm}$ fish are stocked with a stocking density of 20 thousand heads/hectare, with a maintenance period of 50 days. In another study on farmers of the rice-fish system in Klaten, Central Java, fish are planted in rice fields generally for 30 days with fish yields reaching 30-40 fish/kilogram (Sauqie 2016).

\section{Rice planting in the rice-fish integrative farming}

In the rice cultivation activities, when the rice field is overflown (dianglér), the farmers would do babut binih, the process of removing the seedlings raised in the nursery to be planted in the rice fields. The rice seedlings are tied with bamboo ropes and transported to rice fields. The rice seeds are transplanted (tandur) by women in rice fields that have been prepared (dicaplak) by men (Figure 8). 
Tandur must be done by women because women are considered better in seed selection and planting. Besides that, rice planting is more suitable for women because farmers believe that rice has a rice goddess, Nyai Pohaci, or Nyi Pohaci (in Sundanese) or Dewi Sri (in Javanese) who is more comfortable with women than men. Therefore, women farmers, especially in the past before the Green Revolution, have an important role in the selection and cultivation of traditional rice seed varieties (Wessing 1978; Iskandar and Iskandar 2011).

At present, in the Lampegan Village, are new varieties of rice, namely cihérang, mékongga, membramo, inpari 4, inpari 10, inpari 30, inpari 64 and inpari 82 are planted. This is in contrast to the farmers of the rice-fish management in Bunisari Village, Cianjur, who still grow local rice varieties such as dasnéng (markonéng), pandan wangi and ketan hitam (Wardiningsih et al. 2018).

After the tandur process is completed, usually when the rice seedlings are 10 days old, fish seeds are sown in the intercropping model. The intercropping system is followed because fish will not be disturbed by the presence of small rice plants. This also leads to better growth with fish in the rice fields. The fish droppings can also enhance soil fertility and the growth of rice plants.

On 15-20 days after planting rice, the farmers do the first fertilization. The water is sorted first until the third day. This is intended to temporarily move the fish into the trenches in the rice fields that have been prepared during the preparation of the rice fields. Usually, the fertilizers are added by farmers by waiting for two days for the water to rise again, and fertilizer is considered to have been completely absorbed by rice plants.

After fertilization is completed, the rice field is weeded with a latch (garéndél/gasruk), this wedding is usually called ngageréndél or ngagasruk. After that, weeding can also be done by pulling the pest plants manually by women, called ngarambét paré. Ngarambét can also use tools, such as sickle (arit). At the same time, rice fields are also usually sprayed with pesticides, such as poison écéng, lipor, or micin pesticides.

When the rice plants are 30-40 days old, fish are usually harvested. When rice is around 40-50 days old, usually second fertilization is carried out. After that, farmers only have to wait for the rice harvest. Rice harvest is usually carried out 60 days after planting rice. Harvesting is conducted manually, then the rice stalk is struck against a wooden board (digebuk) so that the grains of paddy fall out of the stalk. Next, the paddy is milled to get rice grains.

\section{Maintenance of fish in the rice-fish integrative farming}

In general, the farmers of the rice-fish farming management in the Lampegan Village never provide any special feed to the fish cultured in the rice fields. The fish relies on natural food available in the rice ecosystem. However, some farmers usually provide additional feed in the form of pélét, dedek, and limbah dapur (kitchen waste) for the species of fish that are bred in rice fields. The pélét (fish feed) is obtained from shops while dedek is usually procured from rice mills (Figure 9).

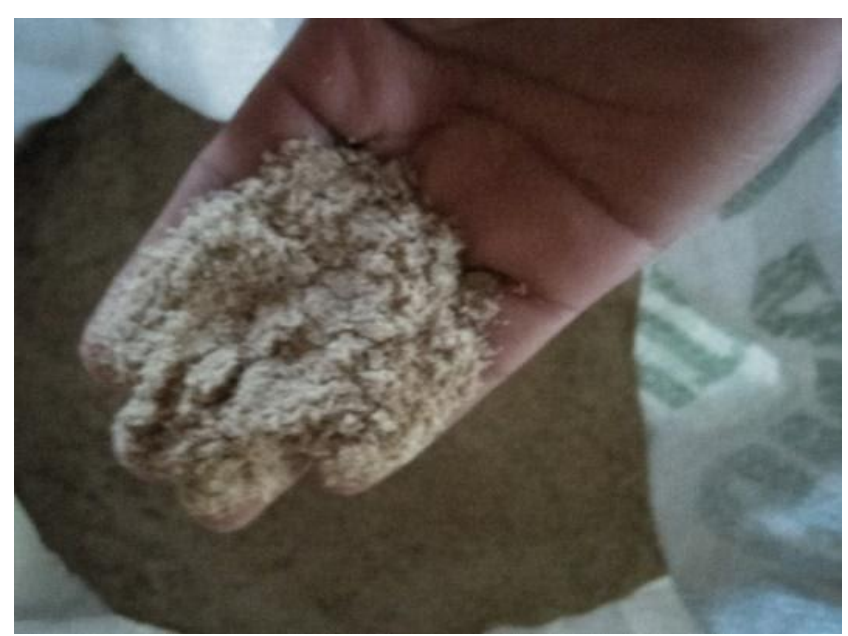

Figure 9. Dedek used as fish feed in the rice-fish integrative farming

Meanwhile, limbah is usually from household kitchens. The kitchen waste is usually boiled and then finely chopped to quickly rot and can be used to fertilize the rice fields, which also triggers the growth of fish in the rice fields.

Fertilizers for rice cultivation are used in the management of the rice-fish integrative farming in the form of inorganic fertilizers, such as urea, TSP, and Phonska fertilizers. Besides, some farmers provide factory-made organic fertilizer, such as super growth that is distributed to farmers. However, this fertilizer has a higher price than urea. Super growth is usually sold at Rp 3,500 per kilogram, while urea is only around Rp 2,500 per kilogram.

Some obstacles are often faced by farmers in managing the rice-fish integrative farming in rice fields, main is the problem of fish pests. According to informants, some wild birds such as wokwok or koak/black-crowned night heron (Nycticorax nycticorax), bird of blekok/Javan pond-heron (Ardeola speciosa), and manuk hurang/kingfisher birds (Alcedo sp), and small mammals like séro/Asian smallclawed otter (Aonyx cinerea) cause problem by preying on domestic fish in the fields. Based on literature (ethics), these species of wild birds and animals were known as predators of various aquatic organisms, including the species of fish in the fields (Iskandar 2015). Besides, maling belut (eel seekers) in rice fields, who usually catch eels with a stunning tool can also be a nuisance to domestic fish in rice-fish integrative farming.

Traditionally, as a countermeasure from eel seekers' disturbances, some farmers of the fish rice integrative farming usually mark their rice fields with wooden or tree trunks stuck in one corner of the rice field. In such fields, the eel seekers will be more careful in using a stunning tool when looking for eels. To combat séro or beaver pests, farmers usually make fences around rice fields and cover trenches with waring. The fence is made very tight and leaning towards inside. This is because séro always come in groups, and they are aggressive and are not afraid of humans.

For controlling the menace of koak/wokwok birds, farmers of the rice-fish integrative farming usually use 
nylon nets (kenur) which are spread out in rice fields. As a result, the birds are trapped into the net, or birds that are not trapped usually return deterred. Meanwhile, pests that usually attack rice plants in the rice-fish integrative farming are beurit/rat (Rattus argentiventer), hama beureum (Tungro disease), and hama bodas (Scirpophaga innotata). Based on village people myth, beurit (rats) are thought to originate from Mount Gede having supernatural powers that are difficult to eradicate. Farmers usually eradicate rats by drying rice fields. After the rice field is drained, it is sprinkled with rat poison (pythons) that have been finely ground and then covered with dedek. Consequently, poisoned rats from eating bran. Rat pest control efforts are usually carried out when the rice plants are 45 days old. More than $25 \%$ of damage is caused by hama beureum or hama bodas pests, farmers usually control it by spraying insecticides/pesticides.

The rat pest control practices are similar to the results of Wali's (2015) which states that in controlling rice pests can be done using physical methods, namely changing the environmental conditions so that it is not preferred or not suitable for pests, and also capturing pests by hand or using pest traps. In addition, farmers also try to eradicate pests by using chemicals, such as insecticides, nematicides, and others.

According to ecological history, before the Green Revolution, farmers usually controlled rice pests in traditional ways such as using biopesticides. Currently, only Baduy farmers in South Banten still practice it. Baduy swidden rice crops are usually attacked by rice pests, such as kungkang pests (Leptocorisa acuta), odd pests (Orseolia oryzae), gaang (Grylottalpa africana) and ongrék/kuuk (Insect larvae) (Iskandar 1998). Usually, these rice pests are controlled by using biopesticides made from cangkudu fruits (Morinda citrifolia), laja rhizomes (Languas galanga), orange fruit peels (Citrus gandris), coconut water (Cocos nucifera), palm wine (Arenga pinata) and furnace ash (lebu hawu). This concoction is usually sprinkled on fields. The leaves of walang (Amomum walang) and leaves of kanyere (Bridelia monoica) are also burned in the edge of the field to eradicate the pests. In addition to pests, another obstacle in the management of the minapadi farming system of Lampegan is water scarcity which often occurs in the dry season and polluted irrigation water.

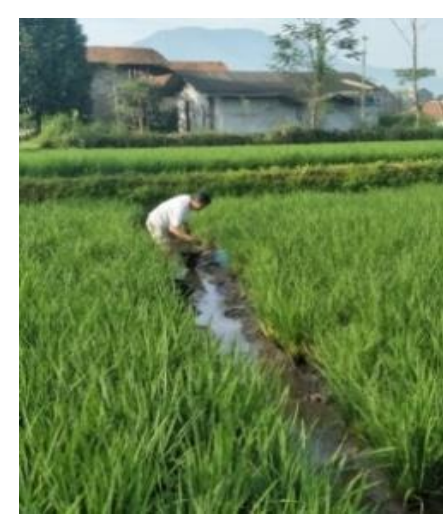

A

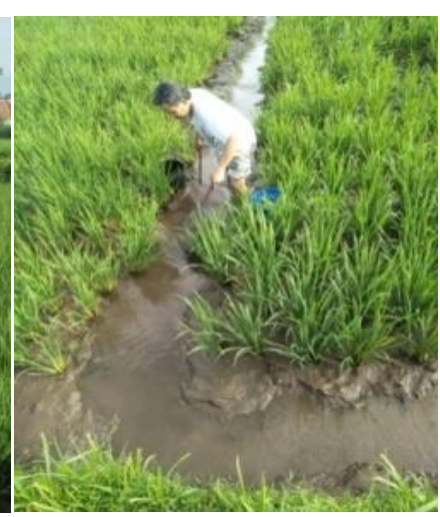

B

\section{Harvesting fish and rice in the rice-fish management}

The methods of harvesting fish in the intermittent and intercropping models are different. In the intermittent system, the fish are usually harvested when the rice fields are planted with rice. The fish age is about 35 days after stocking. Harvesting of fish is done while the water is stored in the rice fields, by letting to gather in a trench or reservoir. The fish that have gathered are then caught using sair.

Meanwhile, in intercropping models, fish are usually harvested 30 days after the fish are stocked in the fields. The length of the harvested fish varies, there are belo/léter size (around 3-5 $\mathrm{cm}$ ) or ngadua ramo (around 5-8 cm). Harvested fish are larger. This is known from the increase in the number of fish léter or kilogram larger than the first planting. The raising is conducted using 1 léter of fish with a total of 200 fish size $1-3 \mathrm{~cm}$, weighing $\pm 5 \mathrm{~g}$ /ind, the fish yield obtained is 3 léters measuring $3-5 \mathrm{~cm}$, weighing $\pm 10 \mathrm{~g} /$ ind.

Harvested fish are collected in reservoirs of clean water, usually using buckets. Fish harvesting does not use laborers but is carried out independently by farmers or together with the head of the rice-fish group. After all the fish have been harvested and placed in a bucket filled with water, they are moved to privately-owned ponds. Two ponds are used, the same as spawning (Figure 10). Utilization of fish in the rice-fish integrative farming

The fish produced from the rice-fish management in the Lampegan Village is usually used for both the family consumption and for sale purposes. Consumed fish can play an important role in fulfilling the protein needs of the family. The usual process of consuming common carp and baby fish of tilapia is generally by frying or grilling. Fish that are not freshly processed are usually dried (dikéré). The steps are: fresh fish are split and then crushed with coriander seasoning (Coriandrum sativum) and dried under the sun till dry. Besides, the local people in the Lampegan Village also often process fish into stews or pressed (dipais). The steps are: the fish wrapped in clean banana leaves (Musa paradisiaca), steamed, and then grilled. Usually, the fish dish is accompanied by raw sambal (sambel atah) or soy sauce. In addition to selfconsumption, ordinary fish yields are also sold to dealers who have previously provided fish seeds (cf. Rahardjo and Kurniawan 2011). Usually, buyers will come directly looking for fish at the port (Figure 11).

Figure 10. A. The process of fish harvesting, B. Catching fish with sair, C. Fish transferred to farmers' ponds, and D. Private fish ponds

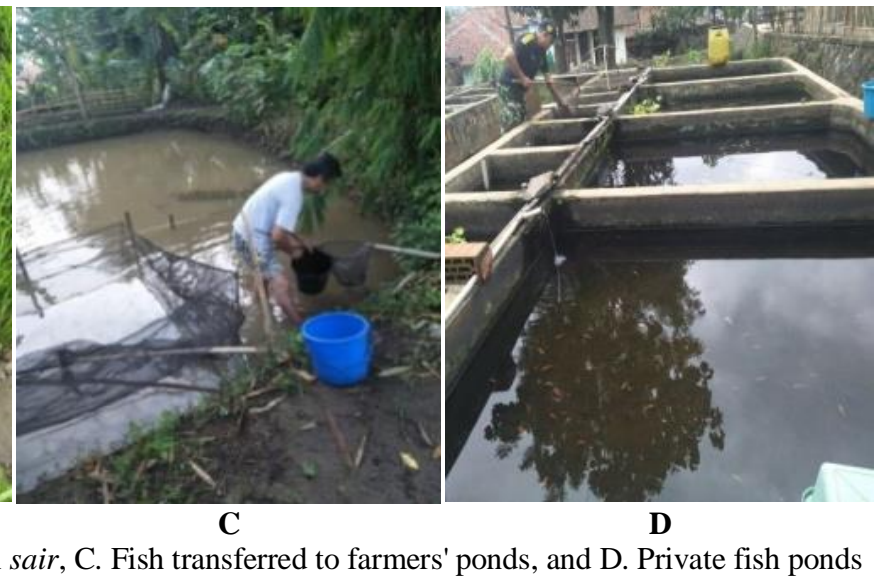




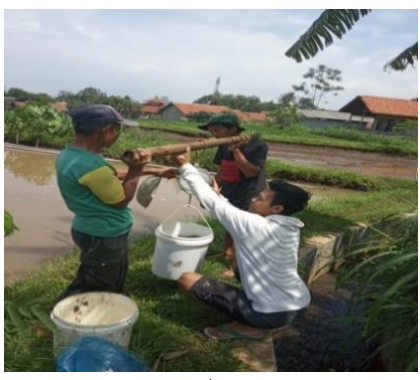

A

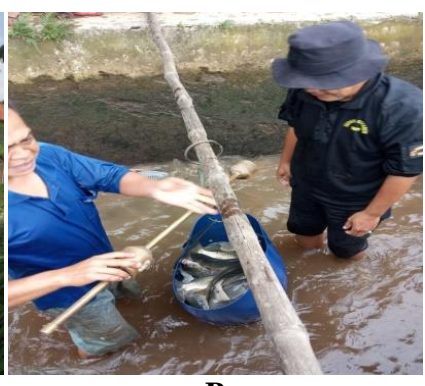

B
Figure 11. A Weighing of harvested fish, and B. Purchasing of fish yields from the rice-fish system

Rice fish farmers in Lampegan Village focus on selling fish production for seed and nursery material. Buyers come from some regions around Bandung and outside of Bandung. However, if farmers want to sell directly to consumers, this is also allowed. Fish will be sold to neighbors or to farmers who need fish seeds to be propagated and to grow. Also, some farmers often collect crops from the group leader to be sold to fish dealers or fish markets. Besides, farmers often also directly sell fish harvests to an ornamental fish shop or Muara Fish Market in Tegalega, Bandung. Ornamental fish is usually sold for Rp 2,000 - 3,000 per individual fish depending on the species and size of the fish. Figure 12 explains the market chain system of the fish from the farmers to dealers and buyers.

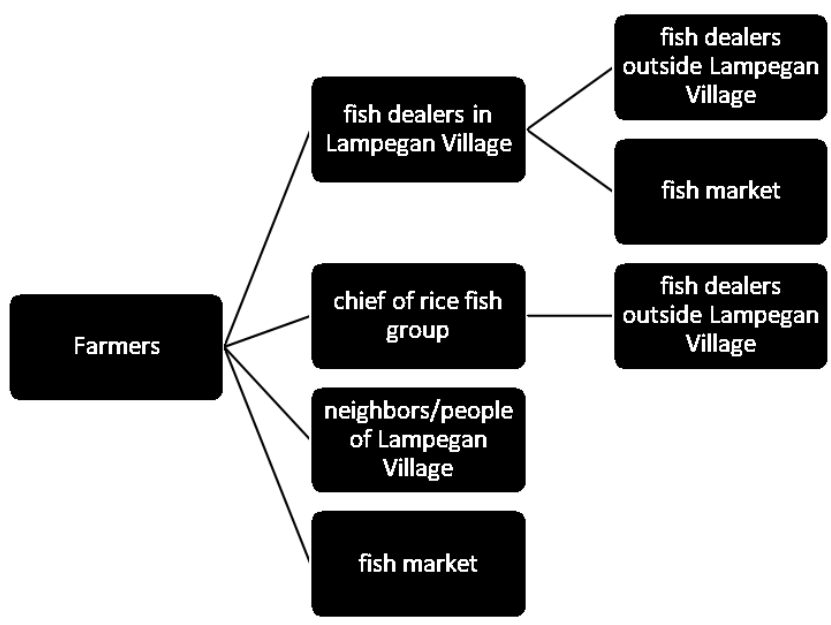

Figure 12. Marketing Chain of fish products

Table 7. The selling value of fish harvested in the village of Lampegan

\begin{tabular}{ll}
\hline Categories of fish & Price $(\mathbf{R p )}$ \\
\hline Common carp & $30,000 / \mathrm{kg}$ \\
Adult tilapias & $25,000 / \mathrm{kg}$ \\
Young tilapias & $25,000 / \mathrm{leter}$ \\
Ornamental fish & $200-500 /$ ind \\
\hline
\end{tabular}

There are fish sold as fresh fish and processed into some meals. Fish processing usually uses baby fish (small fish) for frying. In some process, adult fish are also shredded. This processing is usually done on a home industry scale.

Rice fish farmers have been given training for processing fish into shredded meat. Technical training for the rice-fish integrative farming is usually conducted separately under the group of rice-fish integrative farming farmers and farmers who do not manage the rice-fish integrative farming. Training is often held outside the village, such as in Subang or from BBI (Fish Seed Center) in Ciparay, Bandung District. Besides, it is also common for fisheries extension officers to visit the village. Usually, during the counseling, officers offer assistance in the form of common carp and tilapia seeds.

Lampegan Village farmers usually sell half of the fish produced by the rice-fish integrative farming while the other half is consumed by the family. Usually, the Lampegan Village fish market sells its fish using two systems. First, they use a contracting system or entrust fish seeds in the fields. Second, the system is sold off without sharing the profits. For-profit sharing, they usually do not pay for seeds and no fish yields are given, but by sharing the profits equally or 50: 50. Usually, the production sharing is carried out by the farmers who own the fields and the tenants who do not own the fields but want to do farming.

Table 7 shows that the price of fish at the farmer level is higher for goldfish than tilapias fish. The price of adult tilapias fish is the same as young tilapias. In addition, the selling price of ornamental fish at fish farmer level is only $10 \%$ of the selling price of ornamental fish when it reaches fish traders or farmer groups ( $\operatorname{Rp} 2,000-5,000)$.

Fish yields obtained from the rice-fish system are varied. The harvest yields $25 \mathrm{~kg}$, tilapia $15 \mathrm{~kg}$, and the baby fish tilapia can reach 60 liters. For ornamental fish, it can reach 2,000 individuals per month (land area of 150 tumbak rice fields or $2,100 \mathrm{~cm}^{2}$ ). The community benefits more from the sale of fish in the rice-fish system than only utilizing rice yields. The land used for rice-fish is considered more fertile (leuwih subur) for rice cultivation.

Fish products also often help the farming community to produce capital in the fields, including buying the fertilizer, payment for the workers at the farm labor or land preparation, etc. The results show the local people of Lampegan Village are making a profit of up to $80 \%$ from planting rice fish. Based on interviews with respondents, $32 \%$ stated that the practice of the rice-fish integrative farming increased the income, $60 \%$ said that it reduced production costs, and $8 \%$ said that fish rice added income while reducing production costs.

The results of the study in Lampegan Village are similar to the study results of Ahmed et al. (2011) and Nurhayati (2016) which state that the rice-fish system can decrease the risk of losing sources of income because this system does not depend on a single source, so the failure of one crop will not affect farmers' incomes. It is also considered the most efficient system in reducing costs, especially for the use of fertilizers. 
Ecologically, according to informants, the fish kept in the fields tend to be cepet kagedé (growing faster) compared to maintenance in the pond. Besides, the maintenance of fish in rice-fish integrative farming is easier; as it does not need a pond that must be treated properly. In the rice-fish integrative farming, the rice field ecosystem has provided various inputs for fish growth, such as natural food, sunlight, and water. The rice-fish system also causes soil fertility.

\section{The economic value of paddy-fish integrative farming}

Based on the perception of respondents, rice-fish integrative farming can provide ecological, socioeconomic, and cultural benefits. Ecologically, ricefish management can improve the rice field soils (20\% of respondents), faster fish growth $(52 \%)$, and improved soil fertility and faster fish growth (28\%). Meanwhile, the socio-economic benefits for the community include increasing the nutrition of food sources for the family because the production of fish as well as being sold is also commonly consumed in the family. According to the informants' perception, the taste of fish from the rice-fish integrative farming is better (raos) and savory compared to the taste of fish bred in ordinary fish ponds. Based on the perception of respondents, by consuming fish from the rice-fish integrative farming, family food nutrition increases because it is easy to get fish $(86 \%)$, and can strengthen social relationships and improve family food nutrition (14\%).

Besides, according to residents, the establishment of a rice-fish farming group system can help tighten the kinship (duduluran), and suppress the urbanization of the younger generation who will continue inheritance of knowledge on the rice-fish system to the next generation.

The activities of the rice-fish system are not only beneficial for village farmers but can also benefit for fish dealers, fish hatchers, and fish marketers. The reason is that farmers who do not have a pond usually do profit-sharing with a fishing port or buy seeds from the dealer in the village. The majority of Lampegan Village residents are still related in kinship (dulur), and the existence of the ricefish management could help each other and improve the economy of the village community.

\section{ACKNOWLEDGEMENTS}

The research was funded through the Research Leadership Program (ALG), Universitas Padjadjaran, Sumedang, Indonesia, and is part of a research program of Prof. Johan Iskandar with the theme of "Ethnobiology for Public Welfare on Supporting Sustainable Development". Thanks to the Rector of the Universitas Padjadjaran who has supported the ALG (Academic Leadership Grant) program. Thanks to those who have contributed to this study, and the whole local people of Lampegan Village for all the information provided.

\section{REFERENCES}

Abuasir S, Hakim N, Sumitro Y. 2004. The factors that influence the adoption of the Minapadi farming system in Pujo Rahayu Village, Belitang Sub-district, Ogan Komering Ulu District. J Komunikasi Pengembangan Masyarakat 1 (1): 30-37. [Indonesian]

Admihardja. 1994. People's knowledge and technology systems: Subsistence and environmentally friendly development among Sundanese people in West Java. Bandung: Ilham Jaya. [Indonesian].

Ahmed N. Zander KK, Garnett ST. 2011. Socioeconomics aspects of ricefish farming in Bangladesh: Opportunities, challenges, and production efficiency. Australian J AgriRes Eco 55 (2): 199-219.

Akbar A. 2017. The role of minapadi intensification in increasing the income of lowland rice farmers in Gegong Gegarang, Jagong Jeget Sub-district, Central Aceh District. J S Pertanian 1 (1): 28-38 [Indonesian].

Albuquerque UP, Ramos MA, de Lucena RFP, Alencar. 2014. Methods and techniques used to collect ethnobiological data. In Albuquerque UP, Cruz da Cunha LVF, de Lucena RFP, Alves RRN (eds), Methods and techniques in ethnobiology and ethnoecology. Springer Science + Business Media, New York.

Albuquerque UP, Sousa Araujo TA, Ramos MA, do Nascimento VT, de Lucena RFP, Munteiro JM, de Lima Aranjo E. 2009. How ethnobotany can aid biodiversity conservation: reflections on integration in the semi-arid region of NE Brazil. Biodiv Conserv 18: 127-150.

Berkes F, Colding J, Folke C. 2003. Synthesis: building resiliency and adaptive capacity in social-ecological systems. In: Berkes F, Colding J, Folke C. (eds.). Navigating social-ecological systems: building resilience for complexity and change. Cambridge University Press, Cambridge.

Berkes F. 2008. Sacred Ecology. 2nd ed. Routledge, New York

Cahyaningrum W. 2014. Spatial direction of minapadi development based on land suitability and swot analysis in Cianjur District, West Java. Majalah Ilmiah Globë 16 (1): 77-88 [Indonesian].

Dispakan. 2016. Strategic plan for 2016-2021. Bandung District Food and Fisheries Service, Dispakan, Bandung. [Indonesian]

Erawan TS, Iskandar J, Nuari T. 2017. Knowledge of residents of Karangwangi Cianjur Village, West Java, about the types, fishing techniques, and disturbance of Cikawung River fish. Pro-Life 4 (1): 261-274. [Indonesian].

Fowler CS. 2000. Ethnoecology: An introduction. In: Minnis PE (ed.), Ethnobotany: a reader. University of Oklahoma Press, Norman, OK.

Hadi P. 2014. Rearing fish with rice in the rice fields (minapadi), a potential double benefit for farmers in Bengkulu Province. Dinas Pertanian Provinsi Bengkulu, Bengkulu. [Indonesian].

Halwart M, Gupta MV. 2004. Culture of fish in rice fields. FAO and The World Fish Center, Viale delle Terme di Caracalla, 00100 Rome, Italy

Halwart M. 1998. Trends in rice-fish farming. The FAO Aquaculture Newsletter No. 9, FAO, Rome.

Handojo. 1989. Minapadi. Simpleks, Jakarta. [Indonesian]

Iskandar J, Iskandar BS. 2011. Sundanese Agroecosystem. PT. Kiblat Buku Utama, Bandung. [Indonesian].

Iskandar J. 2015. Biodiversity of animals: function for ecology and human being. Graha Ilmu, Yogyakarta. [Indonesian].

Iskandar J. 2016. Ethnobiology and cultural diversity in Indonesia. Umbara Indonesian J Antropol 1 (1): 27-41. [Indonesian]

Iskandar J. 2018. Ethnobiology, ethnoecology, and sustainable development. Plantaxia, Yogyakarta. [Indonesian].

Khaeron H. 2017. Rice-fish system. Lembang Agricultural Training Center, West Bandung District, Bandung. [Indonesian]

KKP. 2018. Minapadi assistance program. Ministry of Maritime Affairs and Fisheries of the Republic of Indonesia. [Indonesian]

Lantarsih R. (2016). Development of "mini deep ponds" in Sleman District. J Agraris 2 (1): 18-27. [Indonesian].

Lestari 2017. Minapadi application in the context of supporting food security and improving community welfare. Proc Biol Edu Conf 14 (1): 70-74. [Indonesian]

Lestari S. 2017. The maintenance of catfish with rice (minapadi) as a potential for multiple benefits for farmers. J Terapan Abdimas 2: 2732. [Indonesian].

Lovelace GW. 1984. Cultural beliefs and management of agroecosystems. In Rambo AT, Sajise PE (eds.). An introduction to human ecology 
research on agricultural systems in Southeast Asia. East-West Center, Hawaii.

Luo Y, Fu H, Traore S. 2014. Biodiversity Conservation in Rice Paddies in China: Toward Ecological Sustainability. Sustainability 6: 61076124

Martin GJ.1995. Ethnobotany: A Methods Manual. Chapman \& Hall, London.

Newing H, Eagle CM, Puri RK, Watson CW. 2011. Conducting research in conservation: social science methods and practice. Routledge, London.

Nurhayati A. 2016. Derivatives analysis of an economic and social aspect of added value mina padi (Paddy-Fish Integrative Farming) a sase study in the Village of Sagaracipta Ciparay Sub-district, Bandung, West Java Province, Indonesia. Aquatic Procedia 7: 12-18.

Partasasmita R, Nuari T, Tatang SE, Johan I. 2015. The diversity of fish species and the disturbances in the Cikawung river, Cianjur, West Java, Indonesia. Nusantara Biosci 7: 165-170

Rahardjo DPE, Kurniawan M. 2011. Minapadi appointed Bandung District farmers. Compas.co.

Rahmawati AS. 2018. The economic benefits of the minapadi program in Sukabumi District. Department of Resource and Environmental Economics, Bogor Agricultural University, Bogor. [Indonesian]
Sasa J. Syahromi O. 2006. Minapadi system in the perspective of land productivity, income, and the environment. Penelitian Pertanian Tanaman Pangan 25 (2): 1-9. [Indonesian]

Sauqie. 2017. Business analysis of minapadi cultivation activities in the prosperous mina group and murakabidi mina group in Sleman District. J Aquacult Manag Technol 6 (1): 1-7. [Indonesian].

Sudiarta IM, Syam'un E, Syamsuddin R. 2016. The growth and production paddy and tilapia production at legowo row planting system. J Sains Teknologi 16 (1): 70-80.

Suganda AP. 1964. Traditional Ceremony in Pasundan. Penerbit Sumur Bandung, Bandung. [Indonesian]

Toledo VM. 2002. Ethnoecology: a conceptual framework for the study of indigenous knowledge of nature. In Stepp JR, Wydham FS, Zarger RK (eds.). Ethnobiology and Biocultural. The International Society of Ethnobiology, Georgia.

Wali M, Soamole S. 2015. Study of the level of damage caused by leaf pests on red meranti plants (Shorea leprosula) in the PT Persemaian area. Gema Hutani Lestari, Fene Leisela District. J Ilmiah Agribisnis Perikanan (Agrikan UMMU-Ternate) 8 (2): 36-45. [Indonesian]

Wardiningsih S, Syahadat RM, Ramadhan BC, Putri AETD, Putra PT. 2018. The importance of the minapadi cultural landscape in Bunisari Village. Ikraith-Humaniora 2 (2): 95-100 [Indonesian] 